Vol. 2, No. 2, 2015

\author{
I. Yo. Yaremko \\ Doctor of Economics, Professor,
}

L. M. Pylypenko, O. I. Tyvonchuk

$\mathrm{PhD}$ of Economic Sciences, as. prof.,

Lviv Polytechnic National University

\title{
PROBLEMS AND PROSPECTS OF REFLECTING GOODWILL IN ACCOUNTING SYSTEM AND FINANCIAL REPORTING
}

\begin{abstract}
Dynamic development of modern entities in information and knowledge economy is associated with the usage of intangible factors of functioning. It is components of intangible capacity that form information and intellectual resource of the enterprise, determine its competitive position in the market and are the key to efficient operations and the main factor in the formation of its value. However, many components of these informational and intellectual resources often cannot be clearly identified and objectively measured. For this reason, the existing accounting principles provided by almost all systems of standardization, do not imply the recognition and reflection in accounting and financial reporting of significant amount of information and intellectual assets, mainly internally generated.

These arguments largely explain the gap between the market and the book capitalization of modern companies, especially high-tech ones.. For public companies whose stocks are quoted on equity markets, the value of unidentifiable intellectual assets (capital) can be set by assessing the value differences determined on the basis of market mechanisms. For other operating entities it is impossible to formalize the internally generated information and intellectual capacity in any way. This is achievable only in cases of merger, acquisition or takeover of a business (the so-called M\&A agreements), when the difference between the market value of a business and its book value is taken by the buyer on its balance sheet in the form of goodwill. In fact, goodwill has appeared to be almost the only mechanism of recognizing the value of unidentified information and intellectual assets (capital) in enterprise's value formalized in public financial reporting. The need for public representation of internally generated information and intellectual capacity of companies determines the timeliness of the research related to modern developments in accounting.
\end{abstract}

Key words: goodwill, intellectual capital, financial reporting, approaches to assessing goodwill, methods of accounting for goodwill

\section{Origin of goodwill and approaches to its recognition as an object of accounting}

The first mention of goodwill as an economic category and an object of accounting and reporting dates back to the sixteenth century. The original essence of the concept goodwill reflected investor's "good will" to pay for the target firm the sum that exceeded its book value [10]. Later scientists interpreted the category of goodwill much wider as business reputation, business assets, brand, image, corporate governance efficiency, etc. However, scientists could not produce a common approach to the goodwill reflection in accounting either in historical perspective or in the current period of accounting and economics development. In general, the diametrically opposed views of leading scientists on this concept can be traced - from full acceptance and recognition of goodwill in the form of intangible or a cognate specific asset that allows the company to generate excess profits (F. Piksley), or in the form of prepaid expenses related to staff training and improvement of personnel management, which will contribute to the formation of additional product (E. Schmalenbach), - to complete rejection of such an accounting object. For example, a well-known accounting scholar I. Sher considered goodwill as a way to disguising and distorting the balance sheet [7].

Analysis of current scientific research shows that there are different approaches to defining the essence of goodwill. Some of them propose to consider goodwill as a separate, valid internal characteristic of entity's capacity [3]. Consequently, researchers also argue about the economic meaning of the internally generated goodwill necessary to recognize it as an object of accounting. There even appeared scientific papers about the management of positive goodwill creation. In particular, in publication [5] it is proposed to single out ecological goodwill [8] etc. However, such diversity of approaches to the definition of the nature and importance (role) of goodwill in entities' operation and development deepens the problem of uncertainty not only in accounting of goodwill but also in accounting methodology as a whole. 


\section{Yo. Yaremko, L. M. Pylypenko, O. I. Tyvonchuk}

After analyzing reports about the goodwill's first references in popular science articles or in judicial and legal documents $[1-3,7,10]$, it can be concluded that initially goodwill as an individual object in accounting played the role of an investments regulative, as it reflected the surplus amount that the buying company paid over the value of identifiable tangible assets obtained during acquisition. However, given that the acquired investments are recorded on the balance sheet of the acquirer not as one item but as separate particular assets (fixed assets, inventories, funds, requirements etc.), the goodwill, after being recorded on the balance sheet, cannot be considered as a regulative of investments. This conclusion follows from the fact that a regulative cannot exist without the main object (such as depreciation cannot exist without fixed assets, allowance for doubtful debts without receivables, unpaid capital without registered capital etc.).

On the other hand, goodwill cannot be considered as a full-value asset. In the context of this research an asset is considered as a full-value asset if it not only meets the criteria of probability economic benefits and control by the entity, but also the criterion of possible separation from the entity and transfer (as a result of sale, exchange, capital contribution etc.) to other entities.

Really, goodwill cannot be separated, split off from the enterprise (business) to which it is intrinsic. It is impossible to sell it as an individual unit or subject it to any other business transaction that involves its transfer to another entity. Therefore, goodwill has no price, no fair value because it cannot be an object of purchase and sale. On this basis the internally generated goodwill (not related to M\&A-agreements) cannot be considered as an individual economic object, and this leads to arguing the possibility of its recognition as an asset. Despite the fact that the concept of internally generated goodwill is present in some systems of standardization of accounting and financial reporting (e.g., GAAP SFAS 142 "Goodwill and Other Intangible Assets"), such systems don't contain any positive recommendations on the possibilities of the goodwill accounting, but rather point to the impossibility of its recognition.

The economic nature of goodwill is determined by the factors that cause it. Scientists and experts include to these factors the following:

- business reputation of the acquiree (target firm);
- brand, trademarks, patents of the acquired entity;

- customer base and customer loyalty to the brand or the company acquired;

- developed software, other technical and technological developments;

- management culture, business model and well-established business processes, personnel qualifications etc.

Distinguishing the factors of goodwill allows finding out its essence and nature. Such obvious factors form the capacity being additional to that of the identifiable assets of the company. But because of the impossibility of recognizing these factors as accounting objects their capacity is represented by goodwill. In many scientific works these factors of goodwill formation are referred to as its components (elements), that implies so-called "all-in-one-pot" approach to it recognition. This approach is quite simple and easy in application because it does not provide for clear identification with distinguishing value of particular components, but leads to assessing goodwill as a whole, according to the regulatory method, i.e. cost of business acquisition minus the acquired company book value.

The application of such an approach subsequently causes the problems with accounting the goodwill, when it is necessary to confirm whether it generates income or cash flow (and if so, then in what amount), or it is only a "ballast", "toxic assets" on the balance sheet of the combined business. Moreover, "all-in-one-pot" approach deprives of understanding the goodwill's economic matter. It is also completely irrelevant regarding the company's external stakeholders, since the methodology of its subsequent accounting for and representation in financial reporting cannot meet their information requests. "All-in-one-pot" method of recognition and accounting for goodwill actually causes the reflection of "cat in a poke" on the balance sheet, because the structure and purpose of goodwill's components are unknown to the most stakeholders of the company (Fig. 1).

To enhance the relevance of financial reporting indicators for external stakeholders and for the purposes of managing the company, the identification of types or components of goodwill is not only appropriate but absolutely necessary. To overcome existing problems American researchers Steven L. Henning, Barry L. Lewis, Wayne H. Shaw in the article "Valuation of the Components of Purchased 


\section{Problems and prospects of reflecting goodwill in accounting system and financial reporting}

Goodwill" in Journal of Accounting Research [18] proposed to single out four components of goodwill:

1) the write-up of the target firm's assets to fair market value, calculated as the difference between the fair market value of the target firm's assets and their preacquisition book value;

2) the value of the target firm as a going concern, or stand-alone entity, calculated as the difference between the target's preacquisition market value and the target's fair market value of assets;

3) the market's valuation of the synergistic value created by the acquisition, calculated as the combined cumulative abnormal return to the target and the acquirer;

4) any overvaluation of consideration and/or overpayment for the target [18, p. 375-376].

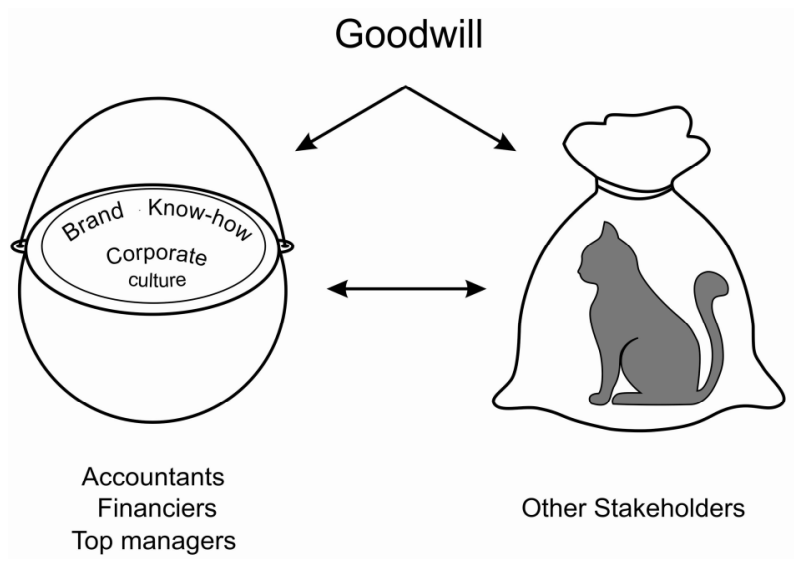

Fig. 1. Illustration of goodwill's perception by the stakeholders in case of "all-in-one-pot" method of its recognition

The given above presentation of goodwill's composition clearly reflects its distinction from intangible assets (since in accordance with some standardization systems of accounting and reporting, including GAAP SFAS 141 "Business Combinations", the term intangible asset excludes goodwill), because besides intellectual objects, it can include the value measurement of the difference in assets evaluation or action of speculative mechanisms in the market.

Expert-analytical agencies in their own methods of business evaluation also take into account the existence of goodwill. A precondition for determining the value of goodwill thereby is a detailed analysis of its composition and origin. For example, evaluative and analytical tool "ValuAdder" provides for the segregation of institutional goodwill related to the operation of business in general, its efficiency and market position etc., and professional practice goodwill, peculiar to the entities that provide professional services - architects, doctors, accountants, auditors, lawyers [19].

In view of the above, the classification of goodwill can be done with the account of at least four criteria - goodwill origin, factors that cause it, its composition, and the subject-carrier of goodwill (Fig. 2).

\section{Evolution of approaches to goodwill evaluation and accounting}

The historical overview makes possible to identify different approaches and methods for evaluating the goodwill proposed by leading scientists, experts and professional accountancy organizations (Table 1).

Table 1

\section{Basic approaches and methods of goodwill valuation}

\begin{tabular}{|c|c|c|}
\hline $\begin{array}{c}\text { Name } \\
\text { of approach } \\
\text { to goodwill } \\
\text { valuation }\end{array}$ & $\begin{array}{c}\text { Essence } \\
\text { of approach } \\
\text { to goodwill } \\
\text { valuation }\end{array}$ & $\begin{array}{c}\text { Methods } \\
\text { of valuation } \\
\text { of goodwill within } \\
\text { a specified approach }\end{array}$ \\
\hline $\begin{array}{l}\text { Residual } \\
\text { (accounting) } \\
\text { approach }\end{array}$ & $\begin{array}{l}\text { Imply goodwill } \\
\text { valuation as the } \\
\text { difference between } \\
\text { the value of busi- } \\
\text { ness and the value } \\
\text { of identifiable assets }\end{array}$ & $\begin{array}{l}\text { Goodwill is calcu- } \\
\text { lated as the difference } \\
\text { between the sum of } \\
\text { cash paid, assets } \\
\text { transferred or other } \\
\text { consideration and the } \\
\text { fair (book) value of } \\
\text { the identifiable assets }\end{array}$ \\
\hline $\begin{array}{l}\text { "Excess" } \\
\text { approach }\end{array}$ & $\begin{array}{l}\text { Based on the assum- } \\
\text { ption, that goodwill } \\
\text { generates "excess" } \\
\text { (additional) econo- } \\
\text { mic benefits for an } \\
\text { entity }\end{array}$ & $\begin{array}{l}\text { Goodwill is evaluated } \\
\text { by measuring the } \\
\text { amount of generated } \\
\text { "excess" profits, } \\
\text { returns, cash flows }\end{array}$ \\
\hline $\begin{array}{l}\text { Value } \\
\text { approach }\end{array}$ & $\begin{array}{l}\text { Based on a compa- } \\
\text { rison of market and } \\
\text { book or replacement } \\
\text { value of entity }\end{array}$ & $\begin{array}{l}\text { Valuation of goodwill } \\
\text { as the difference } \\
\text { between the market } \\
\text { capitalization of the } \\
\text { company and book, } \\
\text { fair or replacement } \\
\text { value of its assets }\end{array}$ \\
\hline $\begin{array}{l}\text { Empirical } \\
\text { approach }\end{array}$ & $\begin{array}{l}\text { Imply goodwill va- } \\
\text { luation by the calcu- } \\
\text { lation of special ra- } \\
\text { tios, multipliers etc. }\end{array}$ & $\begin{array}{l}\text { Valuation of goodwill } \\
\text { by the calculation of } \\
\text { activity ratios, ear- } \\
\text { nings multiples etc. }\end{array}$ \\
\hline $\begin{array}{l}\text { Heuristic } \\
\text { approach }\end{array}$ & $\begin{array}{l}\text { Based on the } \\
\text { application of } \\
\text { heuristic methods }\end{array}$ & $\begin{array}{l}\text { Expert surveys and } \\
\text { other heuristic } \\
\text { methods }\end{array}$ \\
\hline
\end{tabular}

Source: grouped and summarized by the authors on the basis of $[1-4,6,7,9,10]$ 
I. Yo. Yaremko, L. M. Pylypenko, O. I. Tyvonchuk

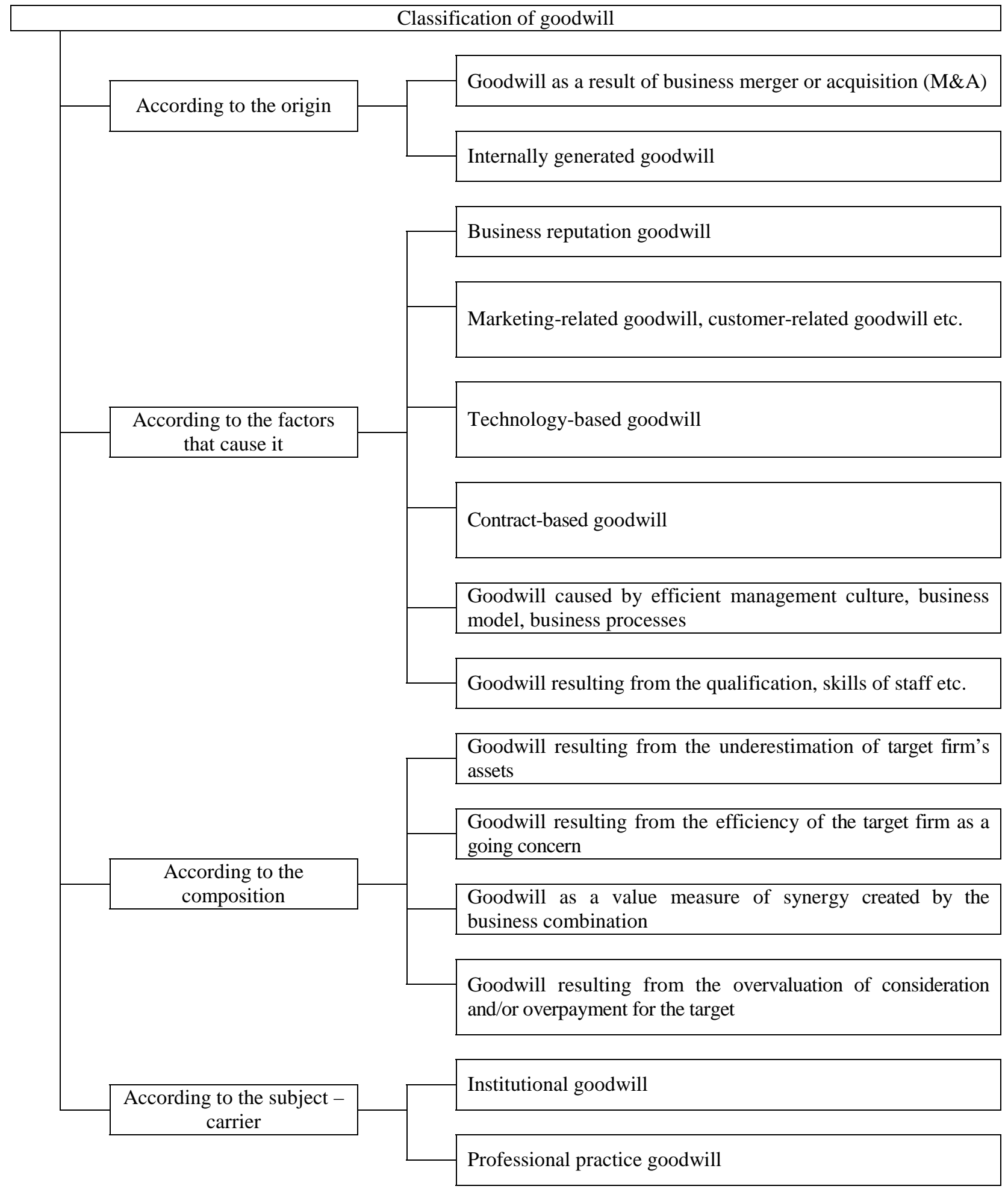

Fig. 2. Classification of goodwill

Source: grouped and summarized by the authors

Each of the listed in the Table 1 approaches and methods for evaluating goodwill has significant shortcomings. Imperative accounting methodology (IFRS, GAAP, National Accounting Regulations (Standards) etc.) actually implies the application of only residual "all-in-one-pot" (or "in total") approach, which disadvantages were mentioned above.

Excess approach requires to single out goodwill's components that are able to generate excess economic benefits. Calculating the surplus of 


\section{Problems and prospects of reflecting goodwill in accounting system and financial reporting}

the obtained economic benefit is based on its amount comparison with some standard values, but it is impossible to establish objective standards for economic benefits (income, return etc.) of market economy entities. And the proposals for calculating of excess economic benefit by its comparison with industry average indicators are, in our opinion, also baseless and mistaken. They do not take into account the existence of goodwill in other industry entities, or the excess is calculated without taking into consideration the average amount of goodwill in the industry, which is also unknown. The problem of excess approach application deepens even more if it is explored within not only the national but also the global economy.

The value approach to the evaluation of goodwill can be considered as a derivative of the "all-in-one-pot" approach. This approach can be applied to the companies whose value is determined by the market mechanism (market capitalization of companies whose shares are quoted on stock exchanges) or empirical evaluation methods. However, the market capitalization can be formed under the influence of speculative mechanisms, and subjectivity of company's appraised value caused by the restrictions and conventionalities of evaluation methods and judgments of appraisers. Thus, it is rather difficult to achieve a high level of objectivity in determining the value of goodwill using value approach.

The validity of goodwill's measurement by the empirical or heuristic approach, in our opinion, is even lower, because the methodology of these approaches is based largely on expert judgment regarding the direct or indirect dependence of goodwill on various quantitative or qualitative factors. In the absence of common approach to determination of economic essence of goodwill the practicability of judgments and indirect estimates application for the formal presentation of relevant information is questionable or even dangerous.

The unified formalization of goodwill is also absent in accounting methodology, therefore, three main approaches to its accounting are used:

1) goodwill's immediate writing off after the acquisition of an entity (business);

2) capitalization as an intangible asset or other special asset with further amortization;

3) capitalization as an intangible asset or other special asset without further amortization, but with periodic impairment test [2].
Methods of assessment and accounting of goodwill if it is recognized depend on the way of accounting of business combinations. Accounting methodology provides two basic methods of accounting transactions on combining businesses (merger, acquisition) - the pooling of interest method and the acquisition method. Since the early 2000 s the main international standardization systems of accounting and reporting (IFRS, GAAP) have offered to apply only the acquisition method for reflecting the business combination transactions in accounting. The key aspects of this method are identifying and determining the acquirer, acquiree, acquisition date, noncontrolling interest, and the reporting unit to which it will be assigned. In accordance with the acquisition method goodwill at the acquisition date is defined as the difference between the fair value of the compensation transferred, the amount of noncontrolling interests and the value of the identifiable assets acquired minus the liabilities assumed [4].

Recognized in accounting goodwill is subject to systematic tests for impairment with the application of the same residual approach as in recognition, but it is not subject to depreciation. At this, goodwill can only be written down (if the fair value of a reporting unit is less than its book value, including goodwill). The write up of goodwill isn't allowed.

Goodwill is valuated (revaluated) not directly as a separate object, but through the relation of fair value and book value of the company, which additionally confirms the lack of goodwill fair value.

On the basis of empirical studies of these components of goodwill Steven L. Henning, Barry L. Lewis, Wayne H. Shaw concluded that two components of goodwill are important for investors the value of the target firm as a stand-alone entity (going-concern) and the synergistic value created by the acquisition (synergy). Given the fact that these two components aren't cost-forming, they aren't subject to amortization either. While the weight of the other two components of goodwill is mostly overstated, investors often write them off the balance sheet in the year of acquisition [18, P. 385-386].

The research done by Steven L. Henning, Barry L. Lewis, and Wayne H. Shaw confirms the expediency and necessity of goodwill's classification by components. Indeed, firstly, the individual components of goodwill can be identified as assets provided there's the possibility of their objective evaluation. In particular, certain intellectual marketing-related or technology-based objects of the acquired company, 


\section{Yo. Yaremko, L. M. Pylypenko, O. I. Tyvonchuk}

which could not be recognized as intangible assets due to the principle of objectification, but can be identified, should be recognized as individual assets after the business acquisition. Such intangible assets can be considered not as self-created, but as acquired, though as part of integral business. And secondly, for individual components of goodwill it is easier to choose the appropriate methods of valuation. For example, marketing or technological components of goodwill can be measured by using the income approach, under which the function of the income indicator can be performed by alternative payments of royalties or franchise etc. In this case, the sum of recognized intangible assets' values should not exceed the amount of goodwill (Fig. 3).

The components that cannot be identified, separated from the business or assessed may be part of goodwill, so, accordingly, they cannot be considered as individual assets and further they are accounted for within goodwill. The part of goodwill induced by the underestimation of the identifiable assets acquired should be written off through revaluation.

In addition to objective factors of mainly intellectual nature the speculative market mechanisms also have an effect on the amount of goodwill, valuated by "all-in-one-pot" approach that provoke its volatility. Through distortion of the entity's value these mechanisms also cause the distortion of the value of its goodwill.

3. The current state of the problem of goodwill representation in financial reporting and approaches to its solution

In the modern information and intellectual economy the problem of the goodwill recognition, assessment, and recording as well as its representation in the financial reporting is becoming increasingly relevant. Especially noticeable it becomes for high-tech companies, whose main resource as well as the manufactured product is intangible by essence.

The inability of recording and reporting of selfcreated intangible objects, that is, unrecognizing them as assets, significantly decreases the book value of such companies and leads to considerable gaps between the market and book value. Moreover, such value gaps can be significant in amount and can exceed the book value of such companies even by several times. These large value gaps can often be observed at high-tech startups' M\&A agreements.

The results of the analysis of the largest M\&A deals of technology sector showed significant amounts of "overpayments" for acquired companies compared to their book value and, as a result, the recording of goodwill with quite high value on the balance sheets of the leading companies. However, the justification of the prices of certain transactions is difficult to understand. In particular, "WhatsApp" Messenger has been acquired by "Facebook" for $\$ 20$ billion. It is hardly believable that "WhatsApp" client capital will be able in the foreseeable future to accumulate additional net cash flow from advertising (the main income generating activity of "Facebook") or other activity of $\$ 20$ billion. Although "WhatsApp" client capital that covers several hundred million messenger users, is considerable, a significant share of the capital probably was already present in "Facebook" before the acquisition of "WhatsApp". The doubts about the objectivity of the transaction price are also caused by the terms of the agreement, since only $\$ 4$ billion from $\$ 20$ billion were paid in cash, and the rest - by the exchange of corporate rights.

The analysis of the M\&A deals of leading technology companies, the comparison of their market and book value and the share of goodwill in them (Table 2) suggest that their managers began to use goodwill as an instrument of formal capitalization of intellectual capital, which could not be recognized and reflected on the balance sheets because of the objectification principle (self-created by the companies intangible assets cannot be recognized). The structure of goodwill in the notes to the annual financial statements is actually revealed through the elements of intellectual capital (Marketing-related (trade names), Technology-based, Customer-related, Contract-based) [11, 12, 17]. The "WhatsApp" takeover alone will enable "Facebook" to almost "align" its market and book capitalization.

The general trend of the number of M\&A deals (more than 60 of Apple, more than 160 of Microsoft, more than 175 of Google, over 50 of Facebook) and their value [13-16] may indicate a further increase of goodwill share in their balance sheets. But won't this form a new "virtual bubble", taking into account the publicity lack of the reasonableness of such deals' prices?! Therefore, to prevent the tendencies of excessive companies' capitalization a principle similar to the principle of objectification should also be applied to goodwill: recognized as a result of business combination transactions goodwill must be evaluated excluding the cost of transferred by the acquirer instruments of owner's equity as consideration in a business combination. 


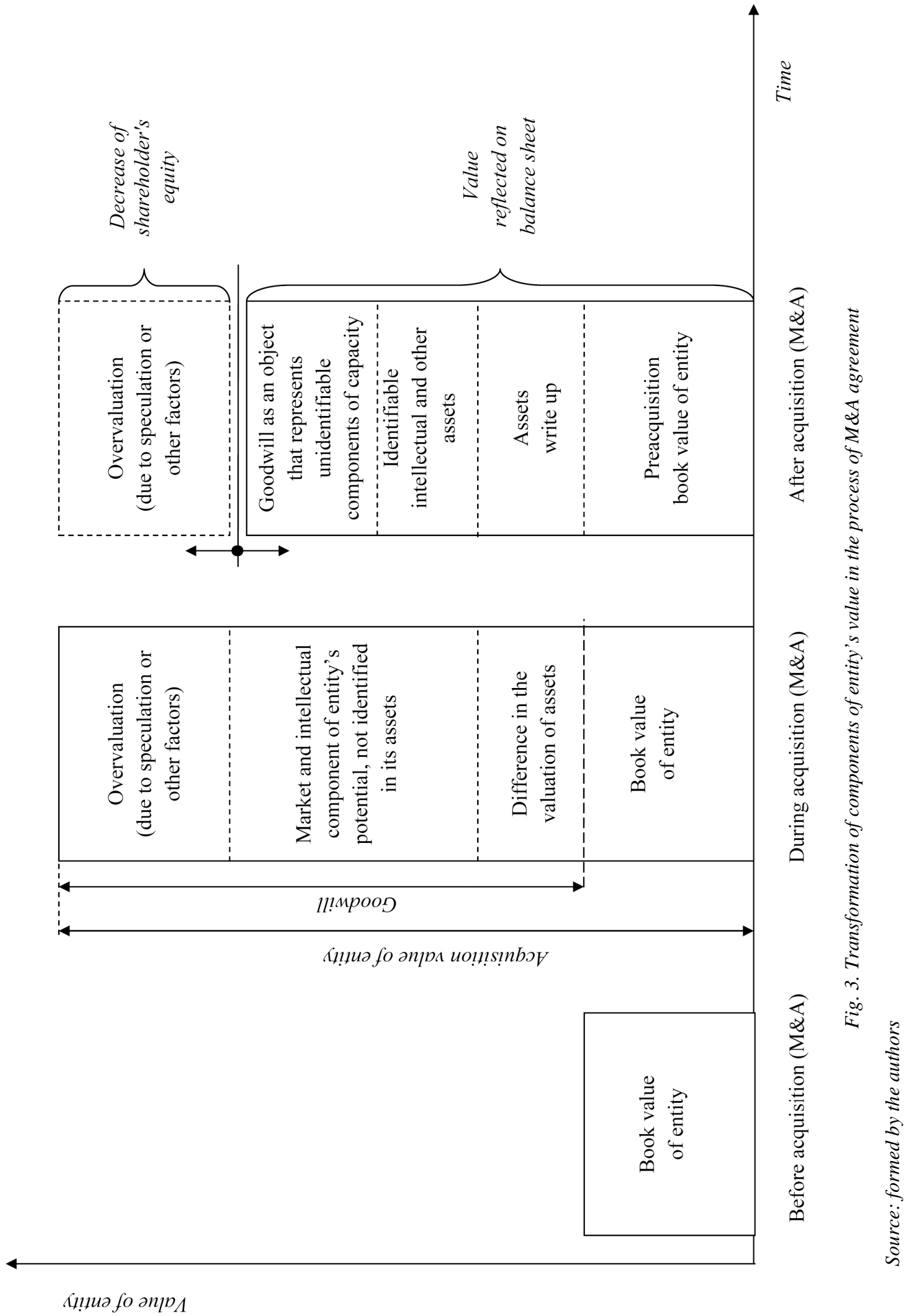




\section{Yo. Yaremko, L. M. Pylypenko, O. I. Tyvonchuk}

Table 2 the industry and technological aspects of their

Market and book value of leading technology companies compared with goodwill relative share

\begin{tabular}{|c|c|c|c|c|c|c|}
\hline \multirow[b]{2}{*}{ 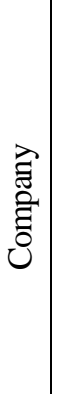 } & \multirow[b]{2}{*}{ 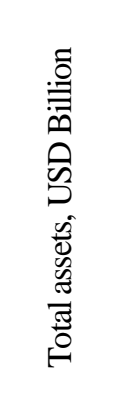 } & \multirow[b]{2}{*}{ 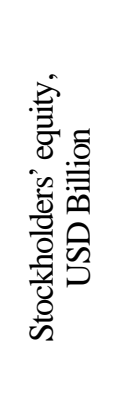 } & \multirow[b]{2}{*}{ 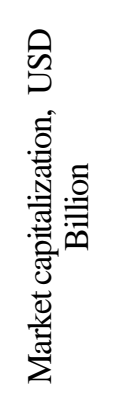 } & \multicolumn{3}{|c|}{ Goodwill } \\
\hline & & & & 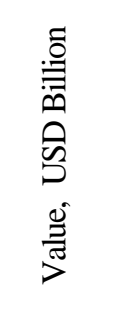 & 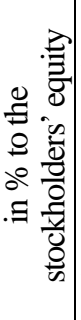 & 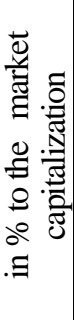 \\
\hline 总 & 231,839 & 111,547 & 462,522 & 4,616 & 4 & 1 \\
\hline 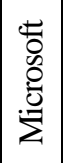 & 169,656 & 90,17 & 284,540 & 20,081 & 22 & 7 \\
\hline $\begin{array}{l}\frac{0}{80} \\
8 \\
0 \\
0\end{array}$ & 125,781 & 98,815 & $\sim 214$ & 15,461 & 16 & 7 \\
\hline 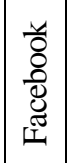 & 24,188 & 21,238 & 49,067 & $2,6121^{1}$ & 12 & 5 \\
\hline
\end{tabular}

Source: grouped and summarized by the author on the basis of $[11,12,17]$

The analysis of the available financial reporting of the largest companies in Ukraine ${ }^{2}$ shows that only in the three out of ten companies' (holdings') consolidated balance sheets the value of goodwill acquired significant values (Table 3). However, unlike the reporting of investigated technology companies (Table 2), the structure of goodwill of Ukrainian economy leaders in the notes to the annual financial statements isn't disclosed (except DTEK Holdings B. V. in 2012), which makes difficult to analyze its essence. Historical analysis of the formation of these holdings and our own opinion on

\section{${ }^{1}$ Excluding the acquisition of WhatsApp}

${ }^{2}$ The sampling has covered the largest (top twenty) companies in accordance with magazine "Forbes. Ukraine" ranking that present their financial statements on the websites in free access activities allow to assume that their goodwill has been created as a result of acquisitions (privatization) of the companies whose balance sheets were significantly underestimated.

Table 3

Analysis of goodwill of the largest companies in Ukraine (as on 31.12.2014)

\begin{tabular}{|c|c|c|c|c|c|}
\hline \multirow[b]{2}{*}{ 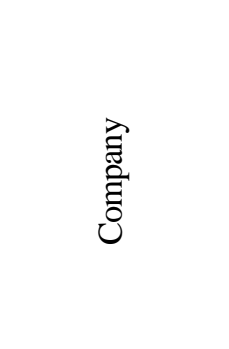 } & \multirow[b]{2}{*}{ 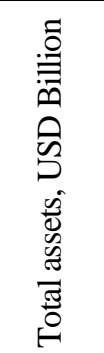 } & \multirow[b]{2}{*}{ 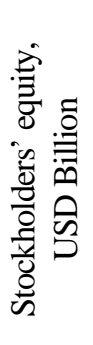 } & \multicolumn{3}{|c|}{ Goodwill } \\
\hline & & & 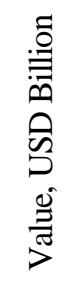 & 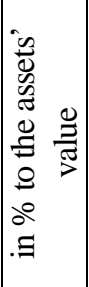 & 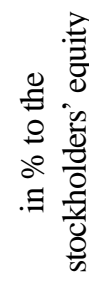 \\
\hline $\begin{array}{l}\text { Ltd. "Metinvest } \\
\text { holding" }\end{array}$ & 12556 & 6762 & 754 & 6 & 11 \\
\hline $\begin{array}{c}\text { DTEK } \\
\text { Holdings B. } \mathrm{V}^{3} .\end{array}$ & 9550 & 4086 & 570 & 6 & 14 \\
\hline $\begin{array}{c}\text { PJSC } \\
\text { "ArcelorMittal } \\
\text { Kryviy Rih" } \\
\end{array}$ & 3240 & 2447 & 0 & 0 & 0 \\
\hline $\begin{array}{c}\text { Kernel } \\
\text { Holding S. A. }\end{array}$ & 1919 & 1031 & 139 & 7 & 13 \\
\hline $\begin{array}{c}\text { PJSC } \\
\text { "Ukrtatnafta", }\end{array}$ & 4072 & 2175 & 0 & 0 & 0 \\
\hline $\begin{array}{l}\text { PJSC "Ferrexpo } \\
\text { Poltava Mining" }\end{array}$ & 579 & 285 & 0 & 0 & 0 \\
\hline $\begin{array}{c}\text { PJSC } \\
\text { "Myronivsky } \\
\text { Hliboprodukt" }\end{array}$ & 2477 & 1156 & 3 & 0,1 & 0,3 \\
\hline $\begin{array}{c}\text { PJSC } \\
\text { "Galnaftogas" }\end{array}$ & 354 & 108 & 0 & 0 & 0 \\
\hline $\begin{array}{c}\text { PJSC } \\
\text { "Kyivstar"4 }\end{array}$ & 1368 & 1087 & 0 & 0 & 0 \\
\hline $\begin{array}{c}\text { PJSC } \\
\text { "Donetsksteel" }\end{array}$ & 577 & 74 & 0 & 0 & 0 \\
\hline
\end{tabular}

Source: summarized by the author on the basis of companies'financial reporting

Conclusions and suggestions. Taking into account the real state of the current financial and economic relations, goodwill becomes the determining accounting object for the companies of information and intellectual economy. The existing methodology of this economic category accounting and its representation in reporting cannot meet the information demands of companies' stakeholders. "All-in-one-pot" method of goodwill recognition

\footnotetext{
${ }^{3}$ As on 31.12 .2012

${ }^{4}$ As on 31.12 .2013
} 


\section{Problems and prospects of reflecting goodwill in accounting system and financial reporting}

accounts for the formation of "a pig in a poke" in the balance sheet, since the nature, structure and purpose of goodwill is unknown to most stakeholders of the companies. Therefore, in order to enhance the relevance of accounting information, it is appropriate to recommend the following improvements of goodwill accounting methodology and representation of the information about it in financial reporting:

1) the recognition of the acquired goodwill should imply its distribution not only by reporting (generating) units but also by components in terms of the factors that cause it. This will permit to recognize goodwill components that represent the intellectual capital of the acquired businesses as intangible assets. These intangible assets can be regarded not as self-created, but as acquired, though as part of the integral business. For intellectual components of goodwill it is easier to choose appropriate assessment methods. At the same time, the sum of recognized intangible assets should not exceed the value of goodwill. The residual value of goodwill would represent the rest of its components, the value of which should be tested for impairment;

2) the description of the composition and structure of goodwill should be included to the notes to the annual financial statements that, on the one hand, will help to raise the level of informativeness of financial reporting and, accordingly, to eliminate the effect of "a cat in a poke" regarding perception of goodwill by the companies' stakeholders, and, on the other hand, to enhance justification of their economic capacity (especially information and intellectual component of it);

3) to prevent the tendencies of excessive companies' capitalization recognized as a result of business combination transactions goodwill must be evaluated excluding the cost of transferred by the acquirer instruments of owner's equity as consideration in a business combination. The mentioned methodological proposal aims to prevent the formation of a "virtual bubble" on the balance sheets of the companies, especially high-tech ones.

\section{References}

1. Бадалова А. Г. Гудвил как составляющчая интелектуального капитала: экономическая сущность, подходы к оченке, риски / А. Г. Бадалова, Ю. А. Еленева, Ю. Я. Еленева // Экономика образования. - 2014. - № 1. - С. 120-122.
2. Бондар М. I. Визначення гудвілу при придбанні підприємства з метою його відображення в обліку / М. І. Бондар // Формування ринкової економіки. - 2010. - № 24. - С. 528-537.

3. Ваганова Л. В. Особливості очінки та визнання в обліку невідчутних активів / Л. В. Ваганова, Н. А. Хрущ, // Вісник Хмельницького національного університету. Економічні науки. - 2009. - № 4. T. 2. - C. 59-64.

4. Міжнародний стандарт фінансової звітності 3 “Об'єднання бізнесу”.

5. Подольна В. В. Формування позитивного гудвілу на малих підприємствах (на прикладі легкої промисловості) : автореф. дис. ... канд. екон. наук : 08.00.04 / В. В. Подольна. - К. : Київ. нац. ун-т технологій та дизайну, 2009. - 17 c.

6. Романів Р. Очінка інтелектуального капіталу та ї̈ застосування в управлінських концепціях епохи глобалізації економіки / Р. Романів // Економічний аналіз. - 2008. - Bun. 2 (18). - C. 390-392.

7. Соколова Н. А. Загадки гудвила / Н. А. Соколова // Финансы и бізнес. - 2005. - № 1. - С. 108-112.

8. Тарасенко С. В. Екологічний гудвіл як елемент вартості сучасного підприємства / С. В. Тарасенко // Вісник СНАУ : Серія "Економіка та менеджмент”. - 2010. - Bun. 5/1. - C. 155-160.

9. Шама Е. И. Комплексный анализ методов оценки гудвила предприятия / Е. И. Шама // Вісник Національного технічного університету “Харківський політехнічний інститут”. - 2010. № 5. - C. 182-188.

10. Уманців Г. Внутрішній гудвіл підприємства. Економічна природа, проблеми оцінки та обліку / Г. Уманців // Бухгалтерський облік $і$ аудит. № 9. - C. 20-23.

11. Apple Inc.: Annual report pursuant to section 13 or 15(d) of the securities exchange act of 1934 (form 10-k) : For The Fiscal Year Ended September 27, 2014.

12. Google Inc. : Quarterly report pursuant to section 13 or 15(d) of the securities exchange act of 1934 (form 10-q) : For The Quarterly Period Ended September 30, 2014

13. List of mergers and acquisitions by Apple / Wikipedia, the free encyclopedia [Електронний ресурс]. - Режим доступy : http://en.wikipedia. org/wiki/List_of_mergers_and_acquisitions_by_Apple.

14. List of mergers and acquisitions by Facebook / Wikipedia, the free encyclopedia [Електронний pecypc]. - Режим достуny : http://en. wikipedia. org/ wiki/List_of_mergers_and_acquisitions_by_Facebook

15. List of mergers and acquisitions by Google / Wikipedia, the free encyclopedia [Електронний pecypc]. - Режсим достуny : http://en. wikipedia. org/wiki/List_of_mergers_and_acquisitions_by_Google 


\section{Yo. Yaremko, L. M. Pylypenko, O. I. Tyvonchuk}

16. List of mergers and acquisitions by Microsoft / Wikipedia, the free encyclopedia [Електронний pecypc]. - Режим достуny : http://en.wikipedia.org/ wiki/List_of_mergers_and_acquisitions_by_Microsoft

17. Microsoft Corporation: Annual report pursuant to section 13 or 15(d) of the securities exchange act of 1934 (form 10-k) : For The Fiscal Year Ended June 30, 2014

18. Steven L. Henning Valuation of the Components of Purchased Goodwill/Steven L. Henning, Barry L.
Lewis, Wayne H. Shaw // Journal of Accounting Research. - 2000. - № 2. - P. 375-386.

19. Business Goodwill / Small business valuation glossary [Електронний ресурс]. - Режим доступу : http:// www.valuadder.com/glossary/business-goodwill.html.

20. Statement of Financial Accounting Standards № 141. Business Combinations.

21. Statement of Financial Accounting Standards № 142. Goodwill and Other Intangible Assets. 